\title{
Analysis on the Declining Subsidy of Chinese Distributed Photovoltaic
}

\author{
Changhui Yang ${ }^{1, *}$, Jingjing Shang ${ }^{1}$ \\ ${ }^{1}$ a School of Management, Hefei University of Technology, Baohe District, Hefei 230009, China
}

\begin{abstract}
China's distributed PV subsidy policy has been constantly adjusted, and it is expected to be reduced to zero by 2020 . This paper measures the different unit electricity subsidies needed of PV under five solar resource regions in the next three years based on the average yield rate of distributed PV and the declining photovoltaic equipment cost due to constant R\&D input and increasingly increased installed capacity. Studies show that the better the solar resource is, the lower the subsidy for unit electricity will be, and subsidies will constantly decline as equipment cost declines. It is expected that zero-subsidy policy will be realized for Zone I, Zone II and Zone III after 2020, but government subsidies are still needed in Zones IV and V. This paper continues to study the $\mathrm{V}$ area and calculates that when the equipment cost drops by an average rate of $11 \%$ per year, the unit electricity subsidy decreases by an average of $26 \%$ per year. Finally, it is proposed that in order to continue to promote the development of China's distributed photovoltaic and enhance investors' confidence, government should gradually and carefully implement the zero-subsidy policy according to the changes in equipment cost and local resource endowments.
\end{abstract}

\section{Introduction}

With the strong support of the country's subsidy policy, China's photovoltaic industry has achieved remarkable results. During the "Twelfth Five-Year Plan" period, the annual growth rate of installed capacity exceeded $50 \%$. The average growth rate of installed capacity of the first two years during the "13th Five-Year Plan" period was $75 \%$. As of the end of 2018, the cumulative installed capacity of photovoltaic power generation in China has exceeded 1.7 Billion kilowatts. As far as distributed PV, the investment and construction of it has culminated nationwide since 2016 and the total installed capacity in 2018 is about 20GW. According to the new policy published by National Development and Reform Commission, the new guidance price of centralized photovoltaic power plant in the I-III resource area that is included in the national fiscal subsidy is determined to be 0.40 yuan (including tax, the same below), 0.45 yuan, and 0.55 yuan / $\mathrm{kWh}$ respectively; the total power generation subsidy standard for industrial and commercial distributed PV using "self-use first, surplus online" mode is adjusted to 0.10 yuan $/ \mathrm{kWh}$ and 0.18 yuan $/ \mathrm{kWh}$ for household distributed PV. The declining of PV subsidies is already accelerating.

Under the current subsidy policy, the annual rate of return on household distributed PV can reach 9\%. However, the decline in subsidies will inevitably affect the income of PV projects and reduce the confidence of investors. Many scholars have studied subsidy policies. Zhang et al. find that the implementation of enhanced long-term subsidy systems and regional promotion policies are extremely important to further diffusion of PV([1]). Xiong et al. study the influence of governmental subsidies on the indexes of different stages of enterprise development. They conclude that subsidies at Early Exploratory Stage can maximize the social and economic effects and subsidies at Intermediate and Mature Stage have little effects on its turnover and aggravate the overcapacity of $\mathrm{PV}([2])$. He et al. calculate the initial investment subsidy and the emission reduction benefit subsidy based on a dynamic model to further promote the development of $\operatorname{PV}([3])$. Shen et al. estimate the optimal solar subsidy based on the analytical framework which takes into account technical environment, health, employment, and electricity accessibility benefits as well as household's social behaviour([4]).

In order to further promote the optimization and adjustment of the fiscal subsidy policy for distributed PV, this paper firstly simulates the photovoltaic equipment cost in the next three years by using two-factor learning curve model, then determine the initial investment cost and the unit generation cost of photovoltaic, and last take a $8 \mathrm{kV}$ household PV project as an example to measure the PV yield without subsidy in China's five major solar resource regions in the next three years. For regions with yield rate lower than the standard rate, the unit subsidy will be simulated, and for others, those regions can launch no subsidy policy, as the following Fig. 1. describes.

\footnotetext{
* Corresponding author: yangchanghui@hfut.edu.cn
} 


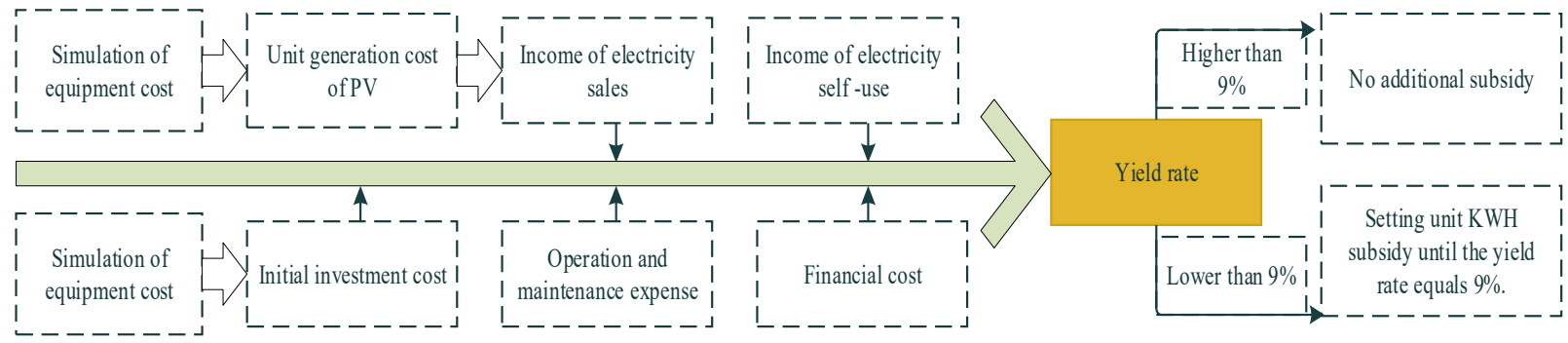

Fig. 1. Principle of the unit KWH subsidy policy.

This paper aims to provide a reference for the establishment of a scientific and reasonable PV subsidy declining mechanism.

\section{Subsidy models}

\subsection{Income model}

The total revenue of distributed PV consists of two parts, one is the revenue saved by self-use and the other is the sales revenue from the surplus electricity.

$$
\begin{gathered}
I_{\text {total }(t)}=\sum_{\mathrm{t}=1}^{\mathrm{n}} I_{\text {sale }(t)}+\sum_{\mathrm{t}=1}^{\mathrm{n}} I_{\text {use }(t)} \\
I_{\text {sale }(t)}=Q_{\text {total }(t)} \times C_{\text {per }} \times\left(1-K_{\text {use }}\right) \\
I_{\text {use }(t)}=Q_{\text {total }(t)} \times P_{\text {use }} \times K_{\text {use }}
\end{gathered}
$$

$t$ represents the service life of the distributed photovoltaic system, $P_{\text {use }}$ represents the residential electricity price, $C_{p e r}$ represents the unit cost of distributed photovoltaic power generation, $K_{\text {use }}$ represents the self-use ratio.

$Q_{\text {total }(t)}$ represents the annual power generation that is determined by installed capacity $M$, peak sunshine hours $H$ and system efficiency $\lambda$ as well as annual PV production reduction rate $\mu_{(t)}$. The formula is expressed as following Eq.(4).

$$
Q_{\text {total }(t)}=M \times \lambda \times H \times\left(1-\mu_{(t)}\right)
$$

\subsection{Cost model}

When the initial investment cost is partly provided by a bank loan, the cash outflow for each year is expressed by the following Eq.(5).

$$
C_{\text {out }(t)}=\left\{\begin{array}{l}
C_{0} \times\left(1-K_{\text {debt }}\right)(t=0) \\
C_{0} \times K_{\text {ope }}+C_{\text {debt }(t)}(1 \leqslant t \leqslant \mathrm{n}-1) \\
C_{0} \times K_{\text {ope }}+C_{\text {debt }(t)}-C_{0} \times K_{\text {scrap }}(t=n)
\end{array}\right.
$$

$C_{0}$ represents the initial investment cost, $K_{\text {debt }}$ represents the loan proportion, $K_{\text {ope }}$ represents the annual operating and maintenance cost rate of initial investment costs, $K_{\text {scrap }}$ represents the residual rate of equipment at the end of operations.

$C_{\text {debt }(t)}$ represents the sum of principal and interest repaid annually due to loans during the repayment period. Under the repayment mode of equal principal and interest, users shall repay the same amount of principal and interest each year, part of which is the principal and part is the interest, just as the following Eq.(6).

$$
C_{\text {debt }(t)}=\left[k_{\text {debt }} \times C_{0} \times I_{\mathrm{int}} \times\left(1+I_{\mathrm{int}}\right)^{m}\right] /\left[\left(1+I_{\mathrm{int}}\right)^{m}-1\right]
$$

$I_{\text {int }}$ represents the loan interest rate provided by bank, $m$ is the repayment period.

The initial investment cost is composed of equipment cost, installation cost, design cost and supplier's profit. The equipment cost accounts for about $70 \%$ of the total initial investment cost, so the $C_{0}$ is calculated as Eq.(7).

$$
C_{0}=C_{\text {equ }} / 0.7
$$

$C_{\text {equ }}$ represents the equipment cost.

The unit cost of photovoltaic power generation is determined by the initial investment cost, operation and maintenance cost, financial cost, and total power generation.

$$
\begin{gathered}
C_{p e r}=\frac{C_{0} \times K_{o p e}+C_{0} \times \mathrm{PVA}+C_{d e b t}}{Q_{\text {total }}} \\
P V A=\frac{i(1+i)^{n}}{(1+i)^{n}-1}
\end{gathered}
$$

The unit cost of PV power generation is mainly affected by the equipment cost and installed capacity. Therefore, the technological progress and the installed 
capacity are two key factors. Combining the cost-learning curve theory with the characteristics of distributed PV, this paper uses a two-factor learning curve to simulate the relationship between distributed equipment cost, cumulative installed capacity and cumulative $R \& D$ investment cost.

$$
C_{e q u(t)}=C^{\prime} \times X(t)^{-\alpha} \times Y(t)^{-\beta}
$$

The unit equipment cost function is defined as $C_{\text {equ(t) }}$; the function of the cumulative installed capacity as change of time is $X(t)^{-\alpha}$; and the function of the R\&D investment cost as change of time is $Y(t)^{-\beta}$, so the unit cost of PV power generation over time is as Eq.(11).

$$
C_{p e r(t)}=\frac{C^{\prime} \times X(t)^{-\alpha} \times Y(t)^{-\beta} / 0.7 \times\left(K_{o p e}+P V A\right)+C_{\text {debt(t) }}}{\lambda_{(t)} \times H \times\left(1-\mu_{(t)}\right)}
$$

\subsection{Subsidy model}

Average annual return on investment $\mathrm{R}=$ (total income total investment) / initial investment / 20, expressed as Eq.(12).

$$
R=\frac{\sum_{t=1}^{n}\left(I_{\text {total }(t)}-C_{\text {out }(t)}\right)}{C_{\text {out }(t=0)} \times 20}
$$

If $\mathrm{R}$ exceeds the standard rate of return of $9 \%$, no subsidy is required. If it is lower than the set standard rate of return, then government needs to continue to implement the subsidy policy. The formula for calculating the required unit KWH subsidy is as follows.

$$
C_{\text {sub }}=\frac{R \times C_{\text {out }(t=0)} \times 20-\sum_{t=1}^{n}\left(I_{\text {total }(t)}-C_{\text {out }(t)}\right)}{\sum_{t=1}^{n} Q_{\text {total }(t)}}
$$

\section{Case analysis}

\subsection{Simulating the equipment cost}

Table 1. 2004-2018 equipment cost of PV.

\begin{tabular}{|c|c|c|c|}
\hline Year & $\begin{array}{c}\text { Equipment } \\
\text { cost } \\
\text { (yuan/w) }\end{array}$ & $\begin{array}{c}\text { cumulative } \\
\text { installed } \\
\text { capacity(M } \\
\text { W) }\end{array}$ & $\begin{array}{c}\text { cumulative } \\
\text { R\&D cost }(\times \\
\mathbf{1 0}^{6} \text { yuan) }\end{array}$ \\
\hline 2004 & 26 & 63 & 193.63 \\
\hline 2005 & 21 & 68 & 441.63 \\
\hline
\end{tabular}

\begin{tabular}{|c|c|c|c|}
\hline 2006 & 18 & 80 & 741.94 \\
\hline 2007 & 16 & 100 & 1112.96 \\
\hline 2008 & 14 & 145 & 1574.56 \\
\hline 2009 & 12 & 373 & 2154.77 \\
\hline 2010 & 10 & 900 & 2861.03 \\
\hline 2011 & 9 & 2900 & 3729.73 \\
\hline 2012 & 8.5 & 6500 & 4759.57 \\
\hline 2013 & 8 & 17500 & 5944.23 \\
\hline 2014 & 7.5 & 28050 & 7245.79 \\
\hline 2015 & 7 & 43180 & 8662.78 \\
\hline 2016 & 6.5 & 77420 & 10230.45 \\
\hline $\begin{array}{c}\text { Average } \\
\text { rate }\end{array}$ & $/$ & $86 \%$ & 17606.1 \\
\hline 2017 & 6.2 & 130530 & 19657.00 \\
\hline rowth & 5.8 & 174630 & $40 \%$ \\
\hline
\end{tabular}

Note: PV equipment cost data comes from academic research results. Cumulative installed capacity data comes from http:/guangfu.bjx.com.cn/news/20180308/884261.shtml, https://baijiahao.baidu.com/s?id=1623349537829494659\&wfr $=$ spider $\&$ for $=p c$. The accumulated $R \& D$ cost data is calculated based on $0.1 \%$ of R\&D funds ( $\mathrm{He}$ et al,2017).

For equation (10), take the logarithm of both sides and get:

$$
\lg C_{e q u(t)}=\lg C^{\prime}-\alpha \lg X(t)^{\prime}-\beta \lg Y(t)^{\prime}
$$

Use the data in Table 1.and performing regression analysis, then the following results in Table 2.will be gotten.

Table 2. The results of regression analysis.

\begin{tabular}{|c|c|c|c|c|c|}
\hline & $\begin{array}{c}\text { Coeffic } \\
\text { ients }\end{array}$ & $\begin{array}{c}\text { Standar } \\
\text { d error }\end{array}$ & t Stat & $\begin{array}{c}\text { P } \\
\text { value }\end{array}$ & $\begin{array}{c}\text { R } \\
\text { squa } \\
\text { re }\end{array}$ \\
\hline Intercept & $\begin{array}{c}2.1082 \\
47\end{array}$ & 0.091827 & $\begin{array}{c}22.95 \\
883\end{array}$ & $\begin{array}{c}2.77 \mathrm{E}-1 \\
1\end{array}$ & 0.98 \\
& & 0956 \\
\hline $\mathrm{X}$ & -0.0368 & 0.018894 & $\begin{array}{c}-1.95 \\
269\end{array}$ & $\begin{array}{c}0.07457 \\
7\end{array}$ & \\
Variable & 9 & & -6.43 & $3.22 \mathrm{E}-0$ & \\
\hline $\mathrm{Y}$ & -0.2757 & 0.042827 & 762 & 5 & \\
Variable & & & \multicolumn{3}{|l}{} \\
\hline
\end{tabular}

So $\alpha=0.03689, \beta=0.2757, \lg C^{\prime}=2.108247, C^{\prime}$ $=128.3060$, and Eq.(14).will be as: 


$$
C_{\text {equ(t) }}=128.3060 \times X(t)^{-0.03689} \times Y(t)^{-0.2757}
$$

From Table 1, the average growth rate of cumulative installed capacity is $86 \%$, and the average growth rate of accumulated R\&D investment cost is $40 \%$, so the cumulative installed capacity and accumulated R\&D investment cost in the next four years can be calculated. And then put them in Eq.(15).the costs of photovoltaic equipment are as follows.

Table 3. 2019-2022 equipment cost of PV.

\begin{tabular}{|c|c|c|c|}
\hline Year & $\begin{array}{c}\text { Equipment } \\
\text { cost } \\
\text { (yuan/w) }\end{array}$ & $\begin{array}{c}\text { cumulative } \\
\text { installed } \\
\text { capacity(M } \\
\text { W) }\end{array}$ & $\begin{array}{c}\text { cumulative } \\
\text { R\&D cost( } \times \\
\mathbf{1 0}^{6} \text { yuan) }\end{array}$ \\
\hline 2019 & 4.80 & 324811 & 27519 \\
\hline 2020 & 4.27 & 604149 & 38527 \\
\hline 2021 & 3.80 & 1123718 & 53938 \\
\hline 2022 & 3.39 & 2090117 & 75514 \\
\hline
\end{tabular}

\subsection{Simulating the unit generation cost of PV}

Assume that the installed capacity of a distributed PV system is $8 \mathrm{~kW}$, and component decays by $3 \%$ in the first year, then it maintains a stable reduction rate of $0.7 \%$ per year; system efficiency is $85 \%$, and system usage term is 20 years; $i=5 \%$, Other data is as follows.

Table 4. Basic data values.

\begin{tabular}{|c|c|}
\hline Symbol & Values \\
\hline$K_{\text {ope }}$ & $3 \%$ \\
\hline$K_{\text {scrap }}$ & $2 \%$ \\
\hline$m$ & 5 \\
\hline$K_{\text {use }}$ & $50 \%$ \\
\hline$K_{\text {debt }}$ & $50 \%$ \\
\hline$I_{\text {int }}$ & $5 \%$ \\
\hline
\end{tabular}

According to the photovoltaic loan policy implemented by China's current 121 banks, the loan period is generally no more than 5 years, the total loan amount generally does not exceed $70 \%$ of the total initial investment cost, and the favourable interest rate is implemented that is adjusted by $1-10 \%$ on the basis of the central bank's benchmark interest rate. Therefore, it is assumed that $m$ equals 5 years, $K_{\text {debt }}$ is $50 \%$, and $I_{\text {in t }}$ is $5 \%$. Besides, the residential electricity prices in different regions are as following Table 5.
Table 5. Residential electricity price.

\begin{tabular}{|c|c|}
\hline Region & $\begin{array}{c}\boldsymbol{P}_{\text {use }} \\
\text { (yuan/kwh) }\end{array}$ \\
\hline I class area & 0.51 \\
\hline II class area & 0.4993 \\
\hline III class area & 0.5483 \\
\hline IV class area & 0.588 \\
\hline V class area & 0.5464 \\
\hline
\end{tabular}

Substituting the above data into the Eq.(11). to obtain the unit generation cost of PV in 2019-2022, as Table 6. From 2019 to 2022, as the cost of photovoltaic equipment continues to decline, the unit cost of photovoltaic power generation is also decreasing, with an average annual decline rate of about $11 \%$, which is basically the same as the decline in equipment costs; and in the five solar resource regions, the unit cost of electricity in Zone I is the lowest, and the unit cost of electricity in Zone $\mathrm{V}$ is the highest. It can be seen that the better the solar resources, the lower the unit cost of electricity.

\subsection{Calculating the yield rate}

After getting $C_{p e r}$, put all the data into Eq.(12)., then the yield rate of distributed PV without subsidy in five regions can be calculated as the following Table 7.and Fig. 2.

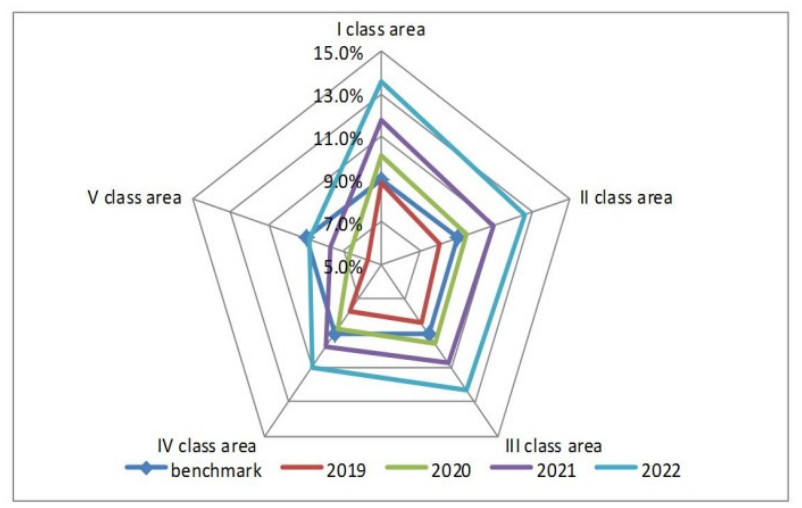

Fig. 2. The rate of return in five regions without subsidy.

Based on the set yield rate of $9 \%$, in the absence of subsidies, the distributed PV projects in 2019 almost lost their appeal in five major regions because the yields were almost all lower than the set rate of return. However, as the initial investment cost declines, the rate of return will be increased year by year. From 2021, in addition to the $\mathrm{V}$ zone, other regions can steadily realize no-subsidy policy. As to the $\mathrm{V}$ zone, although the yield will also rise, it is still below 9\% without subsidy until 2022. Therefore, in the process of promoting distributed 
Table 6. 2019-2022 unit generation cost of PV.

\begin{tabular}{|c|c|c|c|c|c|}
\hline Year & I class area & II class area & III class area & IV class area & V class area \\
\hline 2019 & $3200 \mathrm{~h}-3300 \mathrm{~h}$ & $3000 \mathrm{~h}-3200 \mathrm{~h}$ & $2200 \mathrm{~h}-3000 \mathrm{~h}$ & $1400 \mathrm{~h}-2200 \mathrm{~h}$ & $1000 \mathrm{~h}-1400 \mathrm{~h}$ \\
\hline 2020 & $0.3247-0.3348$ & $0.3348-0.3572$ & $0.3572-0.4870$ & $0.4870-0.7653$ & $0.7653-1.0715$ \\
\hline 2021 & $0.2570-0.2651$ & $0.2651-0.2821$ & $0.2821-0.3865$ & $0.3865-0.6059$ & $0.6059-0.8482$ \\
\hline 2022 & $0.2294-0.2365$ & $0.2365-0.2523$ & $0.2523-0.3440$ & $0.3440-0.5406$ & $0.5406-0.7569$ \\
\hline
\end{tabular}

Table 7. 2019-2022 rate of return in five regions without subsidy.

\begin{tabular}{|c|c|c|c|c|c|}
\hline Year & I class area & II class area & III class area & IV class area & V class area \\
\hline & $3200 \mathrm{~h}-3300 \mathrm{~h}$ & $3000 \mathrm{~h}-3200 \mathrm{~h}$ & $2200 \mathrm{~h}-3000 \mathrm{~h}$ & $1400 \mathrm{~h}-2200 \mathrm{~h}$ & $1000 \mathrm{~h}-1400 \mathrm{~h}$ \\
\hline 2019 & $8.50 \%-9.07 \%$ & $8.00 \%-8.12 \%$ & $7.73 \%-9.05 \%$ & $6.84 \%-8.71 \%$ & $5.34 \%-6.19 \%$ \\
\hline 2020 & $9.77 \%-10.41 \%$ & $9.38 \%-9.59 \%$ & $9.21 \%-10.04 \%$ & $7.99 \%-9.51 \%$ & $6.10 \%-7.25 \%$ \\
\hline 2021 & $11.54 \%-12.00 \%$ & $10.56 \%-11.23 \%$ & $9.51 \%-11.90 \%$ & $9.27 \%-10.33 \%$ & $6.96 \%-8.45 \%$ \\
\hline 2022 & $13.30 \%-13.80 \%$ & $12.21 \%-12.96 \%$ & $10.87 \%-13.76 \%$ & $10.18 \%-11.76 \%$ & $7.89 \%-9.76 \%$ \\
\hline
\end{tabular}

PV with no subsidy, especially in the transition period of the next few years, China has to carefully pay attention to local conditions and launch policies adaptable to different solar resource endowments and changing equipment cost.

\subsection{Simulating the unit KWH subsidy}

For zones that have rate of return lower than $9 \%$, the unit KWH subsidies are calculated as Table 8 using Eq.(14).

According to Table 8, the subsidy policy still must be continued in 2019 and the more subsidies are in areas with poorer solar resource conditions, and the highest subsidy in the V zone is 0.3418 yuan/KWh. After 2020 , subsidies are no longer needed in Zone I, Zone II and Zone III, but in Zones IV and V, especially Zone V, subsidies for electricity are still necessary. Since the V zone has the worst illumination, the following Table 9 is a comparison between the reduction rate of equipment cost and the reduction rate of subsidy needed in Zone $\mathrm{V}$.
Table 9. Subsidies for V class area.

\begin{tabular}{|c|c|c|c|c|}
\hline Year & $\begin{array}{c}\text { PV } \\
\text { equip } \\
\text { ment } \\
\text { cost(y } \\
\text { uan/w) }\end{array}$ & $\begin{array}{c}\text { Declining } \\
\text { percentag } \\
\text { e }\end{array}$ & $\begin{array}{c}\text { Subsidy } \\
\text { for V } \\
\text { class } \\
\text { area(mea } \\
\text { n value) }\end{array}$ & $\begin{array}{c}\text { Declining } \\
\text { percentage }\end{array}$ \\
\hline 2019 & 4.80 & - & 0.2525 & \\
\hline 2020 & 4.27 & $11.04 \%$ & 0.1958 & $22.48 \%$ \\
\hline 2021 & 3.80 & $11.01 \%$ & 0.1441 & $26.41 \%$ \\
\hline 2022 & 3.39 & $10.79 \%$ & 0.0991 & $31.24 \%$ \\
\hline $\begin{array}{l}\text { Mean } \\
\text { value }\end{array}$ & & $10.95 \%$ & & $26.71 \%$ \\
\hline
\end{tabular}

It can be seen that the zone $\mathrm{V}$ needs an average subsidy of 0.2525 yuan/KWh in 2019. In 2020, it needs unit subsidy of 0.1958 yuan/KWh. Until 2022, it still needs 0.0991 yuan/KWh, an average annual drop of $26.71 \%$. The decline of power subsidies is undoubtedly due to the decline in equipment costs. When equipment costs falls by an average rate of about $11 \%$ per year, it can support a $26.71 \%$ reduction rate of electricity subsidies per year under the current PV loan policy and the self-use ratio of $50 \%$.

After calculating the subsidy needed, the final yield rate will be as following Table $\mathbf{1 0}$. 
Table 8. 2019-2022 unit KWH subsidies.

\begin{tabular}{|c|c|c|c|c|c|}
\hline Year & I class area & II class area & III class area & IV class area & V class area \\
\hline & $3200 \mathrm{~h}-3300 \mathrm{~h}$ & $3000 \mathrm{~h}-3200 \mathrm{~h}$ & $2200 \mathrm{~h}-3000 \mathrm{~h}$ & $1400 \mathrm{~h}-2200 \mathrm{~h}$ & $1000 \mathrm{~h}-1400 \mathrm{~h}$ \\
\hline 2019 & $0-0.0069$ & $0.0049-0.0123$ & $0-0.0257$ & $0.0058-0.1453$ & $0.1632-0.3418$ \\
\hline 2020 & 0 & 0 & 0 & $0-0.0968$ & $0.1176-0.2739$ \\
\hline 2021 & 0 & 0 & 0 & $0-0.0537$ & $0.0745-0.2136$ \\
\hline 2022 & 0 & 0 & 0 & $0-0.0162$ & $0.0370-0.1611$ \\
\hline
\end{tabular}

Table 10. 2019-2022 rate of return in five regions with subsidy.

\begin{tabular}{|c|c|c|c|c|c|}
\hline Year & I class area & II class area & III class area & IV class area & V class area \\
\hline & $3200 \mathrm{~h}-3300 \mathrm{~h}$ & $3000 \mathrm{~h}-3200 \mathrm{~h}$ & $2200 \mathrm{~h}-3000 \mathrm{~h}$ & $1400 \mathrm{~h}-2200 \mathrm{~h}$ & $1000 \mathrm{~h}-1400 \mathrm{~h}$ \\
\hline 2019 & $9 \%-9.07 \%$ & $9 \%$ & $9 \%-9.05 \%$ & $9 \%$ & $9 \%$ \\
\hline 2020 & $9.77 \%-10.41 \%$ & $9.38 \%-9.59 \%$ & $9.21 \%-10.04 \%$ & $9 \%-9.51 \%$ & $9 \%$ \\
\hline 2021 & $11.54 \%-12.00 \%$ & $10.56 \%-11.23 \%$ & $9.51 \%-11.90 \%$ & $9.27 \%-10.33 \%$ & $9 \%$ \\
\hline 2022 & $13.30 \%-13.80 \%$ & $12.21 \%-12.96 \%$ & $10.87 \%-13.76 \%$ & $10.18 \%-11.76 \%$ & $9 \%$ \\
\hline
\end{tabular}

\section{Conclusions and suggestions}

The reduction of distributed PV subsidies is an inevitable trend, which will lead to a decline in yield([5]). However, due to the continuous advancement of technology, the cost of photovoltaic equipment is also declining, offsetting the negative impact of declining subsidies, so that the yield of distributed photovoltaic will continue to increase in the next few years. In terms of the set average rate of $9 \%$, areas (I-III) with better light resources can achieve the set rate of return in the next few years even without government subsidies. However, for Zone IV and Zone $\mathrm{V}$, especially Zone $\mathrm{V}$, government subsidies are needed to reach $9 \%$. The highest unit electricity subsidy required for 2019 is 0.3418 yuan, 0.2739 yuan for 2020, 0.2136 yuan for 2021, and 0.1611 yuan for 2022. Therefore, in the process of promoting zero-subsidies policy, China should pay attention to different resource endowments in different regions. At the same time, it is necessary to increase investment in research and development, and let the market compete freely, and continue to develop high-efficiency, low-cost photovoltaic equipment, so as to continue to promote the long-term development of distributed photovoltaic.

\section{ACKNOWLEDGEMENT}

This work is supported by the National Natural Science Foundation of China Grant No. 71771076.

\section{References}

1. Y. Zhang, J. Song, and S. Hamori, Impact of subsidy policies on diffusion of photovoltaic power generation. Energy Policy, 39, 4: 1958-1964 (2018)

2. Y. Xiong, and X. Yang, Government subsidies for the Chinese photovoltaic industry. Energy Policy, 99: 111-119 (2016)

3. Y. He, Y. Pang, X. Li, and M. Zhang, Dynamic subsidy model of photovoltaic distributed generation in China. Renewable Energy, 118: 555-564 (2018)

4. S. Liu, G. Colson, N. Hao, and M. Wetzstein, Toward an optimal household solar subsidy. A social-technical approach. Energy, 147: 377-387 (2018)

5. X. Yang, L. He, Y. Xia, and Y. Chen, Effect of government subsidies on renewable energy investments. The threshold effect. Energy Policy, 132: 156-166 (2019) 